\title{
A-503083 A, B, E and F, Novel Inhibitors of Bacterial Translocase I, Produced by Streptomyces sp. SANK 62799
}

\author{
Yasunori Muramatsu, Takashi Ohnuki, Michiko Miyazawa Ishil, Masaaki Kizuka, \\ Ryuzo Enokita, Shunichi Miyakoshi, Toshio Takatsu and Masatoshi Inukai \\ Lead Discovery Research Laboratories, Sankyo Co., Ltd., \\ 1-2-58 Hiromachi, Shinagawa-ku, Tokyo 140-8710, Japan \\ (Received for publication February 9, 2004)
}

\begin{abstract}
Novel nucleoside antibiotics were isolated from the cultured broth of the strain classified as Streptomyces sp. SANK 62799. The strain produced four novel capuramycin derivatives designated as A-503083 A, B, E and F. Their structures were elucidated as $2^{\prime}$ - $O$-carbamoyl derivatives of A-500359 A, B (capuramycin), E and F, respectively. A-503083 A, B, E and F inhibited bacterial phospho- $\mathrm{N}$-acetylmuramyl-pentapeptide-translocase (translocase I: EC 2.7.8.13) with $\mathrm{IC}_{50}$ values of $0.024,0.038,0.135$ and $17.9 \mu \mathrm{m}$, respectively.
\end{abstract}

Bacterial phospho- $N$-acetylmuramyl-pentapeptide-translocase (translocase I) is an enzyme that is essential and specific for bacteria. It catalyzes the first step in the lipid cycle of peptidoglycan biosynthesis. Translocase I inhibitors such as A-500359 $\mathrm{A}^{1)}$, capuramycin ${ }^{2,3)}$ and mureidomycins ${ }^{4.5)}$ exhibit antimicrobial activity without any toxicities.

In the course of our screening for bacterial translocase I inhibitors, we found inhibitory activity in the cultured broth of Streptomyces sp. SANK 62799. The strain produced four novel capuramycin derivatives designated as A-503083 A, B, E and F (Fig. 1). In this paper, we describe the taxonomy and fermentation of the producing microorganism, isolation, physico-chemical properties, structure elucidation and biological activities of A-503083 $\mathrm{A}, \mathrm{B}, \mathrm{E}$ and $\mathrm{F}$.

\section{Materials and Methods}

\section{Materials}

Undecaprenylphosphate was purchased from Larodan Fine Chemicals. Preparation methods for translocase I and a fluorescent substrate (UDP-MurNAc-L-Ala- $\gamma$-D-Glu- $m$ DAP-[Ne-dansyl]-D-Ala-D-Ala) were previously reported. ${ }^{1}$
Taxonomy of the Producing Organism

The producing organism, strain SANK 62799, was isolated from a soil sample collected in Naha city, Okinawa prefecture, Japan. Methods and media described by the International Streptomyces Project (ISP) ${ }^{(6)}$ and WAKSMAN ${ }^{7)}$ were used to determine the morphological and physiological properties of the producing organism. The cell wall and whole-cell hydrolysates were analyzed by the methods of HASEGAWA et al. $^{8)}$

\section{Fermentation of Strain SANK 62799}

Two loopfuls of spores from a culture of strain SANK 62799 were inoculated into each of two 2-liter Erlenmeyer

Fig. 1. Structures of A-503083 A, B, E and F.

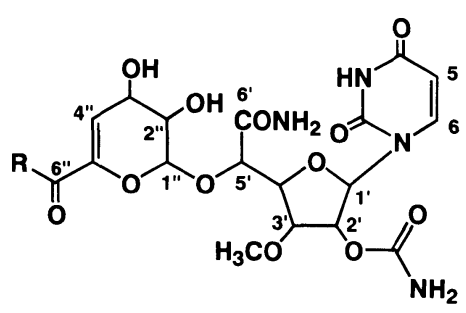

A-503083 A

A-503083 B

* Corresponding author: yasuno@shina.sankyo.co.jp 
flasks containing $500 \mathrm{ml}$ of sterilized seed medium consisting of glucose $2 \%$, soluble starch $1 \%$, pressed yeast $0.9 \%$, Polypepton (Nihon Seiyaku) $0.5 \%$, meat extract (Kyokuto) $0.5 \%, \mathrm{NaCl} 0.5 \%, \mathrm{CaCO}_{3} \quad 0.3 \%$ and $\mathrm{CB}-442$ (NOF Co., Ltd.) $0.01 \%, \mathrm{pH} 7.4$. The inoculated flasks were incubated on a rotary shaker $(210 \mathrm{rpm})$ at $28^{\circ} \mathrm{C}$ for 4 days. Then a $450-\mathrm{ml}$ aliquot of the culture was transferred into each of two 30-liter jar fermentors containing 15 liters of a sterilized culture medium consisting of glucose $5 \%$, soy bean meal $1 \%$, Polypepton $0.4 \%$, meat extract $0.4 \%$, yeast extract (Difco) $0.1 \%, \mathrm{NaCl} 0.25 \%, \mathrm{CaCO}_{3} \quad 0.5 \%$ and CB442 $0.02 \%, \mathrm{pH} 7.2$. Fermentation was carried out at $28^{\circ} \mathrm{C}$ for 7 days with an air-flow rate of 15 liters/minute and agitation rate of $150 \mathrm{rpm}$.

\section{Measurement of Translocase I Inhibitory Activity}

The method used to measure translocase I inhibitory activity was previously reported. ${ }^{1)}$ Briefly, $50 \mu \mathrm{l}$ of $200 \mathrm{~mm}$ Tris-HCl buffer ( $\mathrm{pH} 7.5$ ) containing $100 \mathrm{~mm} \mathrm{KCl}$ and $50 \mathrm{~mm} \mathrm{MgCl} 2$ were added to each well of a 96-well microtitre polystyrene plate (Corning Coaster, \#3694) followed by the addition of $12 \mu \mathrm{l}$ of water and $10 \mu \mathrm{l}$ of $3.15 \mathrm{mg} / \mathrm{ml}$ UDP-MurNAc-L-Ala- $\gamma$-D-Glu- $m$-DAP- $\left(N^{\varepsilon}\right.$ dansyl)-D-Ala-D-Ala (UDP-MurNAc-[ $N^{\varepsilon}$-Dns]pentapeptide). Then, $8 \mu \mathrm{l}$ of lipid solution containing $2.5 \mathrm{mg} / \mathrm{ml}$ phosphatidylglycerol, $3.65 \mathrm{mg} / \mathrm{ml}$ undecaprenylphosphate and $10 \%(\mathrm{v} / \mathrm{v})$ Triton $\mathrm{X}-100$ were added to the assay mixture followed by the addition of the test sample. The reaction was started by the addition of $20 \mu \mathrm{l}$ of the stored enzyme solution $(0.625 \sim 2.5 \mu \mathrm{g}$ protein). The enzyme activity was monitored by measuring the increase in fluorescence at $538 \mathrm{~nm}$ (excitation at $355 \mathrm{~nm}$ ).

\section{Antimicrobial Activities}

MICs were determined by the agar dilution method using Mueller Hinton agar (Becton Dickinson and Company).

\section{General Experimental Procedures}

The various NMR spectra were obtained on a Brucker AMX 360 or AVANCE 500 spectrometer. FAB-MS spectra were recorded on a JEOL JMS-700QQ mass spectrometer. LC-MS/MS spectrum was obtained on a Thermoquest LCQ mass spectrometer. Optical rotations were recorded on a JASCO DIP-370 spectropolarimeter. UV spectra were obtained on a Shimadzu UV-265FW spectrometer. Fluorescence was measured at room temperature on a fluorescence spectrophotometer, Fluoroskan Ascent (Labsystems)
Fig. 2. Scanning electron micrograph of the strain SANK 62799 on humic acid-vitamin agar at $28^{\circ} \mathrm{C}$ for 7 days.

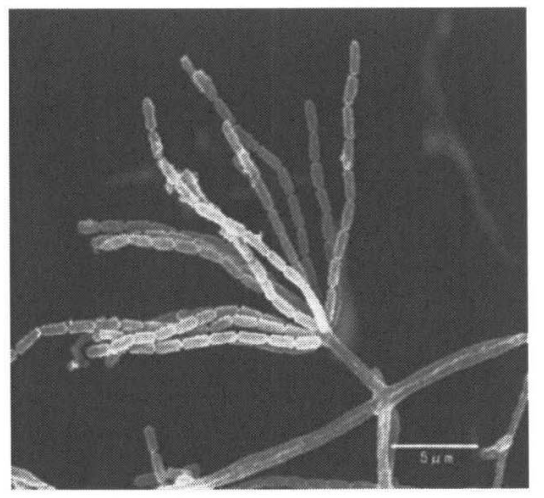

\section{Results}

Taxonomy of Strain SANK 62799

Strain SANK 62799 formed primary or secondary verticils of straight to flexuous spore chains. Most spores were oblong and $0.6 \sim 0.9 \times 0.9 \sim 1.4 \mu \mathrm{m}$ in size with a smooth surface (Fig. 2). The cultural characteristics of the various agar media at $28^{\circ} \mathrm{C}$ for 14 days are presented in Table 1. The physiological properties of the strain and the type of carbon source utilized are summarized in Table 2. The vegetative mycelium was pale yellowish brown to light olive gray and the aerial mycelium was yellowish gray.

The whole-cell hydrolysates of the strain contained LLdiaminopimelic acid. Based on the taxonomic properties described above, the strain was classified as Streptomyces and was named Streptomyces sp. SANK 62799. The strain SANK 62799 was deposited in the International Patent Organism Depositary, National Institute of Advanced Industrial Science and Technology, Ibaraki Prefecture, Japan with the accession number FERM BP-7201.

\section{Isolation of A-503083 A, B, E and F}

The isolation procedure for A-503083 A, B, E and F is shown schematically in Fig. 3. First, the culture filtrate (22 liters) was adjusted to $\mathrm{pH} 2.0$ with $1 \mathrm{~N} \mathrm{HCl}$ and adsorbed onto a SEPABEADS SP207 column (4 liters, Mitsubishi Chemical Corporation). The column was washed successively with $0.04 \%$ aqueous trifluoroacetic acid (9 liters) and water ( 8 liters). The active substances were eluted stepwise with $15 \%$ aqueous $\mathrm{MeOH}$ (fraction 1: 12 liters), 20\% aqueous $\mathrm{MeOH}$ (fraction 2: 16 liters), 30\% 
Table 1. Cultural characteristics of the strain SANK 62799.

\begin{tabular}{|c|c|c|}
\hline Agar Media & & Strain SANK 62799 \\
\hline \multirow{4}{*}{$\begin{array}{l}\text { Yeast extract-malt extract agar } \\
\text { (ISP-2) }\end{array}$} & $G^{a}:$ & Abundant, raised, light olive gray (5Y $8 / 4$ ) \\
\hline & AM: & Good, velvety, yellowish gray (5Y 9/1) \\
\hline & R: & Light olive gray (5Y $8 / 4)$ \\
\hline & SP: & None \\
\hline \multirow{4}{*}{$\begin{array}{l}\text { Oatmeal agar } \\
\text { (ISP-3) }\end{array}$} & G: & Good, raised, pale yellowish brown (2.5Y $7 / 3)$ \\
\hline & AM: & Poor, velvety, yellowish gray (5Y 9/1) \\
\hline & R: & Pale yellowish brown $(2.5 Y 7 / 3)$ \\
\hline & SP: & None \\
\hline \multirow{4}{*}{$\begin{array}{l}\text { Inorganic salts-starch agar } \\
\text { (ISP-4) }\end{array}$} & G: & Good, raised, light olive gray (5Y 8/4) \\
\hline & AM: & Abundant, velvety, pale brown $(2.5$ Y $8 / 2)$ \\
\hline & R: & Light olive gray (5Y $8 / 4)$ \\
\hline & SP: & None \\
\hline \multirow{4}{*}{$\begin{array}{l}\text { Glycerol-asparagine agar } \\
\text { (ISP-5) }\end{array}$} & G: & Good, raised, pale yellowish brown $(2.5 \mathrm{Y} 7 / 6)$ \\
\hline & AM: & Abundant, velvety, yellowish gray (5Y 9/1) \\
\hline & R: & Dark brown $(5$ YR $3 / 3)$ \\
\hline & SP: & None \\
\hline \multirow{4}{*}{$\begin{array}{l}\text { Peptone-yeast extract-iron agar } \\
\text { (ISP-6) }\end{array}$} & G: & Moderate, raised, dark gray $(7.5 \mathrm{Y} 3 / \mathrm{N})$ \\
\hline & AM: & None \\
\hline & R: & Dark gray $(7.5 Y 3 / \mathrm{N})$ \\
\hline & SP: & None \\
\hline \multirow{4}{*}{$\begin{array}{l}\text { Tyrosine agar } \\
\text { (ISP-7) }\end{array}$} & G: & Abundant, raised, yellowish brown (2.5Y 5/6) \\
\hline & AM: & Abundant, velvety, pale pink (7.5R $7 / 3)$ \\
\hline & R: & Dark brown (5YR 3/3) \\
\hline & SP: & None \\
\hline \multirow[t]{4}{*}{ Sucrose-nitrate agar } & G: & Moderate, raised, yellowish gray (5Y 9/1) \\
\hline & AM: & Good, velvety, pale brown (7.5YR 8/3) \\
\hline & R: & Yellowish gray $(5 Y$ 9/1) \\
\hline & SP: & None \\
\hline \multirow[t]{4}{*}{ Glucose-asparagine agar } & G: & Poor, flat, dull yellow ( 5 Y $8 / 8$ ) \\
\hline & AM: & Poor, yellowish gray (5Y 9/1) \\
\hline & R: & Dull yellow $(5 Y 8 / 10)$ \\
\hline & SP: & None \\
\hline \multirow{4}{*}{$\begin{array}{l}\text { Nutrient agar } \\
\text { (Difco) }\end{array}$} & G: & Moderate, flat, light olive gray (5Y $8 / 4$ ) \\
\hline & AM: & Poor, velvety, yellowish gray (5Y 9/1) \\
\hline & R: & Light olive gray (5Y $8 / 4)$ \\
\hline & SP: & None \\
\hline \multirow[t]{4}{*}{ Potato extract-carrot extract agar } & G: & Good, flat, yellowish gray ( 7.5 Y 9/2) \\
\hline & AM: & Abundant, velvety, light brownish gray (10YR $8 / 2$ \\
\hline & R: & Yellowish gray $(7.5 Y$ 9/2) \\
\hline & SP: & None \\
\hline \multirow[t]{4}{*}{ Water agar } & G: & Poor, flat, yellowish gray ( 5 Y 9/1) \\
\hline & AM: & Moderate, velvety, pale brown ( 7.5 YR $8 / 3)$ \\
\hline & R: & Pale yellow $(5 Y$ 9/3) \\
\hline & SP: & None \\
\hline
\end{tabular}

aG: Growth, AM: Aerial mycelium, R: Reverse, SP: Soluble pigment.

aqueous $\mathrm{MeOH}$ (fraction 3: 16 liters) and 50\% aqueous $\mathrm{MeOH}$ (fraction 4: 24 liters).

Isolation of A-503083 F: Fractions 1, 2 and 3 of the first column eluate were combined, concentrated in vacuo and lyophilized to give a crude powder $(27.7 \mathrm{~g})$. Then, a $25-\mathrm{mg}$ sample of the powder was dissolved in water and further purified by preparative HPLC using a Pegasil ODS column (20 i.d. $\times 250 \mathrm{~mm}$, Senshu Scientific) with acetonitrile and
$0.04 \%$ aqueous trifluoroacetic acid $(1.8: 98.2)$ as a mobile phase (flow rate: $10 \mathrm{ml} /$ minute). An active material was eluted at 17.1 minutes as a single peak, and thus the peak fraction was collected. This procedure was repeated 20 times. The eluates were combined and concentrated in vacuo to $10 \mathrm{ml}$. Then, the solution was applied on a TOYOPEARL HW40-F column $(100 \mathrm{ml}$, TOSOH Corporation). After the column was developed with 
Table 2. Physiological properties of the strain SANK 62799.

\begin{tabular}{|c|c|c|}
\hline \multicolumn{2}{|l|}{ Hydrolysis of starch } & $t^{a}$ \\
\hline \multicolumn{2}{|c|}{ Liquefaction of gelatin } & $-b$ \\
\hline \multicolumn{2}{|c|}{ Reduction of nitrate } & - \\
\hline \multicolumn{2}{|c|}{ Coagulation of milk } & - \\
\hline \multicolumn{2}{|c|}{ Peptonization of milk } & + \\
\hline \multicolumn{2}{|c|}{ Production of melanoid pigment } & - \\
\hline \multirow[t]{3}{*}{ Decomposition of } & Casein & - \\
\hline & Tyrosine & - \\
\hline & Xanthine & - \\
\hline \multicolumn{2}{|c|}{ Temperature range for growth ${ }^{c}$} & $4 \sim 40^{\circ} \mathrm{C}$ \\
\hline \multicolumn{2}{|c|}{ Optimum temperature for growth ${ }^{c}$} & $14 \sim 35^{\circ} \mathrm{C}$ \\
\hline \multicolumn{2}{|c|}{ Sodium chloride resistance $^{c}$} & $5 \%$ \\
\hline \multirow[t]{9}{*}{ Utilization of } & D-Glucose & + \\
\hline & L-Arabinose & - \\
\hline & D-Xylose & - \\
\hline & Inositol & + \\
\hline & D-Mannitol & - \\
\hline & D-Fructose & - \\
\hline & L-Rhamnose & - \\
\hline & Sucrose & - \\
\hline & Raffinose & - \\
\hline
\end{tabular}

${ }^{a}$ Utilization. ${ }^{b}$ No utilization.

'Observed on yeast extract-malt extract agar (ISP-2) acetonitrile and $0.04 \%$ aqueous trifluoroacetic acid (6:94), the active fractions were collected, concentrated in vacuo and lyophilized to give A-503083 F as a colorless powder (84.0 mg).

Isolation of A-503083 B and E: Fraction 4 of the first column eluate was concentrated in vacuo and lyophilized to give a crude powder $(30.9 \mathrm{~g})$. Then, the powder $(2 \mathrm{~g})$ was dissolved in $10 \mathrm{ml}$ of water, and the solution was adsorbed onto a MCI GEL CHP20P column $(100 \mathrm{ml})$. After the column was washed with water $(200 \mathrm{ml})$, active materials were eluted stepwise with $15 \%$ aqueous $\mathrm{MeOH}$ (fraction BE: $300 \mathrm{ml}$ ) and $30 \%$ aqueous $\mathrm{MeOH}$ (fraction A: $300 \mathrm{ml}$ ). Each fraction was separately concentrated in vacuo and lyophilized to give crude powders $(506 \mathrm{mg}$ and $308 \mathrm{mg}$, respectively). The powder of fraction $\mathrm{BE}$ was dissolved in $5 \mathrm{ml}$ of acetonitrile and $0.04 \%$ aqueous trifluoroacetic acid (9:91), and the solution was applied on a TOYOPEARL HW40-F column ( $100 \mathrm{ml})$. After the column was developed with acetonitrile and $0.04 \%$ aqueous trifluoroacetic acid (6:94), an active fraction was collected, concentrated in vacuo and lyophilized to give a crude powder $(230 \mathrm{mg})$. The powder was dissolved in $2 \mathrm{ml}$ of acetonitrile and $0.04 \%$

Fig. 3. Isolation procedure of A-503083 A, B, E and F.

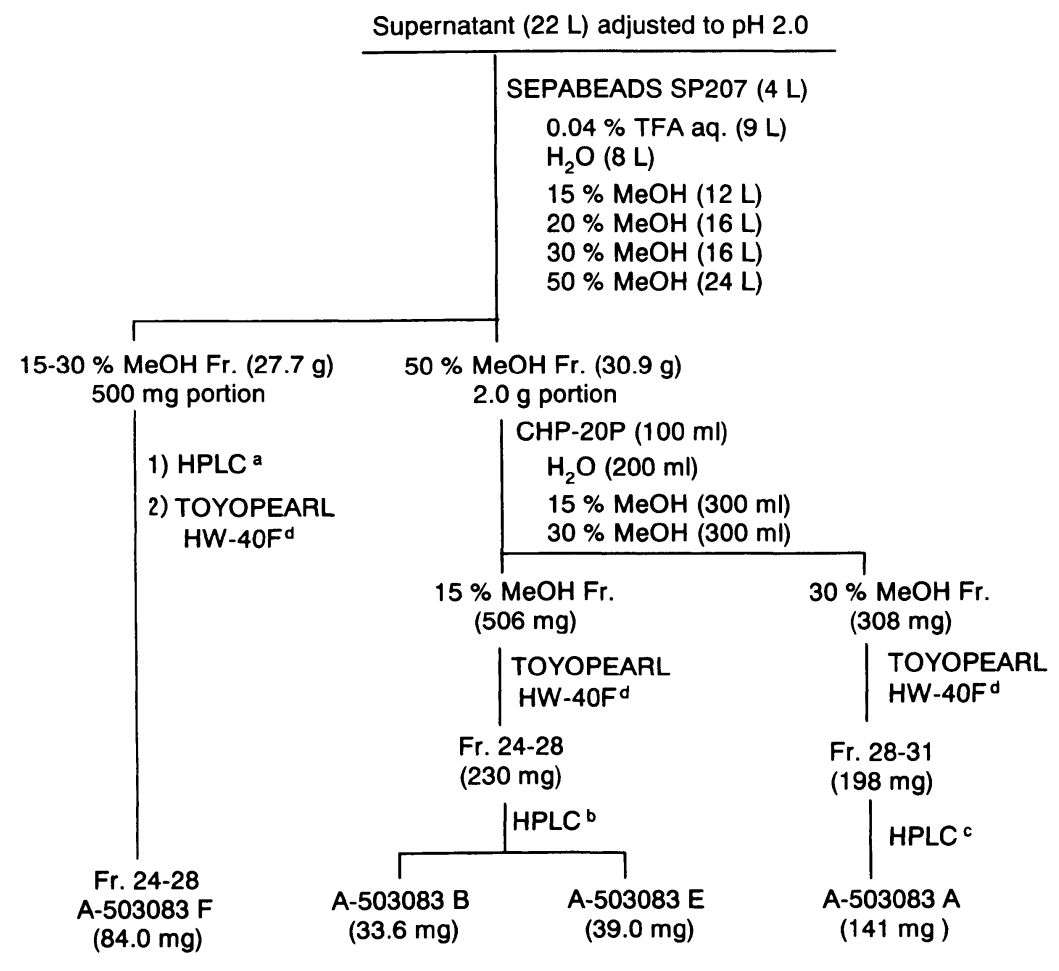

${ }^{\text {a} P e g a s i l ~ O D S, ~} \phi 20 \times 250 \mathrm{~mm}, 1.8 \% \mathrm{CH}_{3} \mathrm{CN} / 0.04 \%$ TFA aq., $10 \mathrm{ml} / \mathrm{minute}$, detect: UV $260 \mathrm{~nm}$.

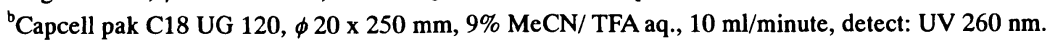

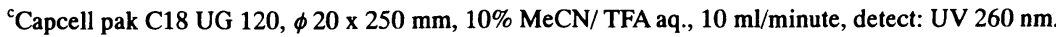
${ }^{\mathrm{d}}$ TOYOPEARL HW-40F, $100 \mathrm{ml}, 6 \% \mathrm{CH}_{3} \mathrm{CN} / 0.04 \%$ TFA aq. 
Table 3. Physico-chemical properties of A-503083 A, B, E, and F.

\begin{tabular}{|c|c|c|c|c|}
\hline & A-503083 A & A-503083 B & A- $503083 \mathrm{E}$ & A-503083 F \\
\hline $\begin{array}{l}\text { Appearance } \\
\text { Solubility }\end{array}$ & Colorless powder & Colorless powder & Colorless powder & Colorless powder \\
\hline Soluble & $\mathrm{H}_{2} \mathrm{O}, \mathrm{MeOH}$ & $\mathrm{H}_{2} \mathrm{O}, \mathrm{MeOH}$ & $\mathrm{H}_{2} \mathrm{O}, \mathrm{MeOH}$ & $\mathrm{H}_{2} \mathrm{O}, \mathrm{MeOH}$ \\
\hline $\begin{array}{l}\text { Insoluble } \\
{[\alpha]_{D}^{29}}\end{array}$ & $\begin{array}{l}\text { Acetone, } \mathrm{CHCl}_{3} \\
+84.0^{\circ} \\
\left(\text { c } 0.7, \mathrm{H}_{2} \mathrm{O}\right)\end{array}$ & $\begin{array}{l}\text { Acetone, } \mathrm{CHCl}_{3} \\
+91.0^{\circ} \\
\left(\text { c } 0.2, \mathrm{H}_{2} \mathrm{O}\right)\end{array}$ & $\begin{array}{l}\text { Acetone, } \mathrm{CHCl}_{3} \\
+61.0^{\circ} \\
\left(\text { c } 0.2, \mathrm{H}_{2} \mathrm{O}\right)\end{array}$ & $\begin{array}{l}\text { Acetone, } \mathrm{CHCl}_{3} \\
+110^{\circ} \\
\left(\text { c } 0.3, \mathrm{H}_{2} \mathrm{O}\right)\end{array}$ \\
\hline $\mathrm{UV} \lambda_{\max }{ }^{\mathrm{H}_{2} \mathrm{O}} \mathrm{nm}(\varepsilon)$ & $257(11000)$ & $257(10900)$ & $250(9190)$ & $259(7980)$ \\
\hline Molecular formula & $\mathrm{C}_{25} \mathrm{H}_{34} \mathrm{~N}_{6} \mathrm{O}_{13}$ & $\mathrm{C}_{24} \mathrm{H}_{32} \mathrm{~N}_{6} \mathrm{O}_{13}$ & $\mathrm{C}_{19} \mathrm{H}_{24} \mathrm{~N}_{4} \mathrm{O}_{13}$ & $\mathrm{C}_{18} \mathrm{H}_{22} \mathrm{~N}_{4} \mathrm{O}_{13}$ \\
\hline FAB-MS $(m / z)$ & $627[\mathrm{M}+\mathrm{H}]^{+}$ & $613[\mathrm{M}+\mathrm{H}]^{+}$ & $517[\mathrm{M}+\mathrm{H}]^{+}$ & $503[\mathrm{M}+\mathrm{H}]^{+}$ \\
\hline HR-FAB-MS $(m / z)$ & $\mathrm{C}_{25} \mathrm{H}_{35} \mathrm{~N}_{6} \mathrm{O}_{13}$ & $\mathrm{C}_{24} \mathrm{H}_{33} \mathrm{~N}_{6} \mathrm{O}_{13}$ & $\mathrm{C}_{19} \mathrm{H}_{25} \mathrm{~N}_{4} \mathrm{O}_{13}$ & $\mathrm{C}_{18} \mathrm{H}_{23} \mathrm{~N}_{4} \mathrm{O}_{13}$ \\
\hline Calcd.: & 627.2262 & 613.2106 & 517.1418 & 503.1262 \\
\hline Found: & 627.2259 & 613.2108 & 517.1424 & 503.1255 \\
\hline $\mathrm{IR}(\mathrm{KBr}) \mathrm{cm}^{-1}$ & $\begin{array}{l}3360,3101,2935, \\
1780,1687,1516, \\
1459,1131,1387, \\
1361,1336,1299, \\
1269,1214,1159 \\
1064,1021,976\end{array}$ & $\begin{array}{l}3362,2936,2860, \\
1684,1515,1463, \\
1437,1387,1359, \\
1335,1270,1209, \\
1144,1020,975\end{array}$ & $\begin{array}{l}3359,3200,2954, \\
2845,1686,1605, \\
1463,1442,1389, \\
1333,1306,1269 \\
1213,1142,1118, \\
1087,1065,1026, \\
977\end{array}$ & $\begin{array}{l}3359,3196,2939 \\
1685,1464,1391, \\
1357,1336,1270 \\
1232,1208,1117 \\
1064,1020,977\end{array}$ \\
\hline
\end{tabular}

aqueous trifluoroacetic acid $(9: 91)$. Then, a 200- $\mu$ l aliquot was injected into the HPLC column [Capcell pak C18 UG 120,20 i.d. $\times 250 \mathrm{~mm}$, SHISEIDO; mobile phase: acetonitrile and $0.04 \%$ aqueous trifluoroacetic acid $(9: 91)$; flow rate: $10 \mathrm{ml} / \mathrm{minute}$, and active materials $(\mathrm{Rt}=25.2$ minutes and 17.7 minutes) were collected. The same procedure was repeated 10 times. The respective fractions were combined, concentrated in vacuo and lyophilized to give A-503083 B (33.6 mg) and A-503083 E (39.0 mg), as colorless powders.

Isolation of A-503083 A: The powder of Fraction A $(308 \mathrm{mg}$ ) was dissolved in $2 \mathrm{ml}$ of acetonitrile and $0.04 \%$ aqueous trifluoroacetic acid (6:94), and the solution was applied on a TOYOPEARL HW40-F column $(100 \mathrm{ml})$. After the column was developed with acetonitrile $-0.04 \%$ aqueous trifluoroacetic acid $(6: 94)$, the active fraction was collected, concentrated in vacuo and lyophilized to give a crude powder $(198 \mathrm{mg})$. The powder was dissolved in $0.5 \mathrm{ml}$ of acetonitrile $-0.04 \%$ aqueous trifluoroacetic acid (1:9). A 100- $\mu$ l aliquot was injected into an HPLC column [Capcell pak C18 UG 120, 20 i.d. $\times 250 \mathrm{~mm}$; mobile phase: acetonitrile $-0.04 \%$ aqueous trifluoroacetic acid ( $1: 9)$; flow rate: $10 \mathrm{ml} / \mathrm{minute}$, and the same procedure was repeated 10 times. Since an active material was eluted at 25.5 minutes as a single peak, the peak fraction was collected, concentrated in vacuo and lyophilized to give A-503083 A as a colorless powder (140 mg).

Physico-chemical Properties of A-503083 A, B, E and F

The physico-chemical properties of A-503083 A, B, E and $F$ are summarized in Table 3 . The molecular formulae of A-503083 A, B, E and F were determined by high resolution FAB-MS to be $\mathrm{C}_{25} \mathrm{H}_{34} \mathrm{~N}_{6} \mathrm{O}_{13}, \mathrm{C}_{24} \mathrm{H}_{32} \mathrm{~N}_{6} \mathrm{O}_{13}$, $\mathrm{C}_{19} \mathrm{H}_{24} \mathrm{~N}_{4} \mathrm{O}_{13}$ and $\mathrm{C}_{18} \mathrm{H}_{22} \mathrm{~N}_{4} \mathrm{O}_{13}$, respectively. Because of the similarity in the physico-chemical properties of these compounds to those of A-500359s, ${ }^{9,10)}$ they were considered to be A-500359-related compounds.

\section{Elucidation of the Structures}

Based on the physico-chemical properties and ${ }^{13} \mathrm{C}$ and ${ }^{1} \mathrm{H}$ NMR data (Table 4), the structure of A-503083 F was considered to be highly related to that of A-500359 F. ${ }^{10)}$ Thus, the structure of A-503083 F was elucidated based on a comparison study with A-500359 F. The observation of two exchangeable proton signals (6.59 and $6.86 \mathrm{ppm})$, the appearance of a carbonyl carbon signal (155.1 ppm) and the low field shift of the $2^{\prime}$ proton signal (4.38 to $5.12 \mathrm{ppm}$ ) were characteristic to A-503083 F. Knowing that C, H, $\mathrm{N}$ and $\mathrm{O}$ atoms were present and based on the precise analysis by ${ }^{1} \mathrm{H}_{-}^{15} \mathrm{~N}$ HSQC and ${ }^{1} \mathrm{H}-{ }^{13} \mathrm{C}$ HMBC, the 6.59 and 
Table 4. ${ }^{13} \mathrm{C}$ and ${ }^{1} \mathrm{H}$ signal assignments for A-503083 A, B, E and F in DMSO- $d_{6}$.

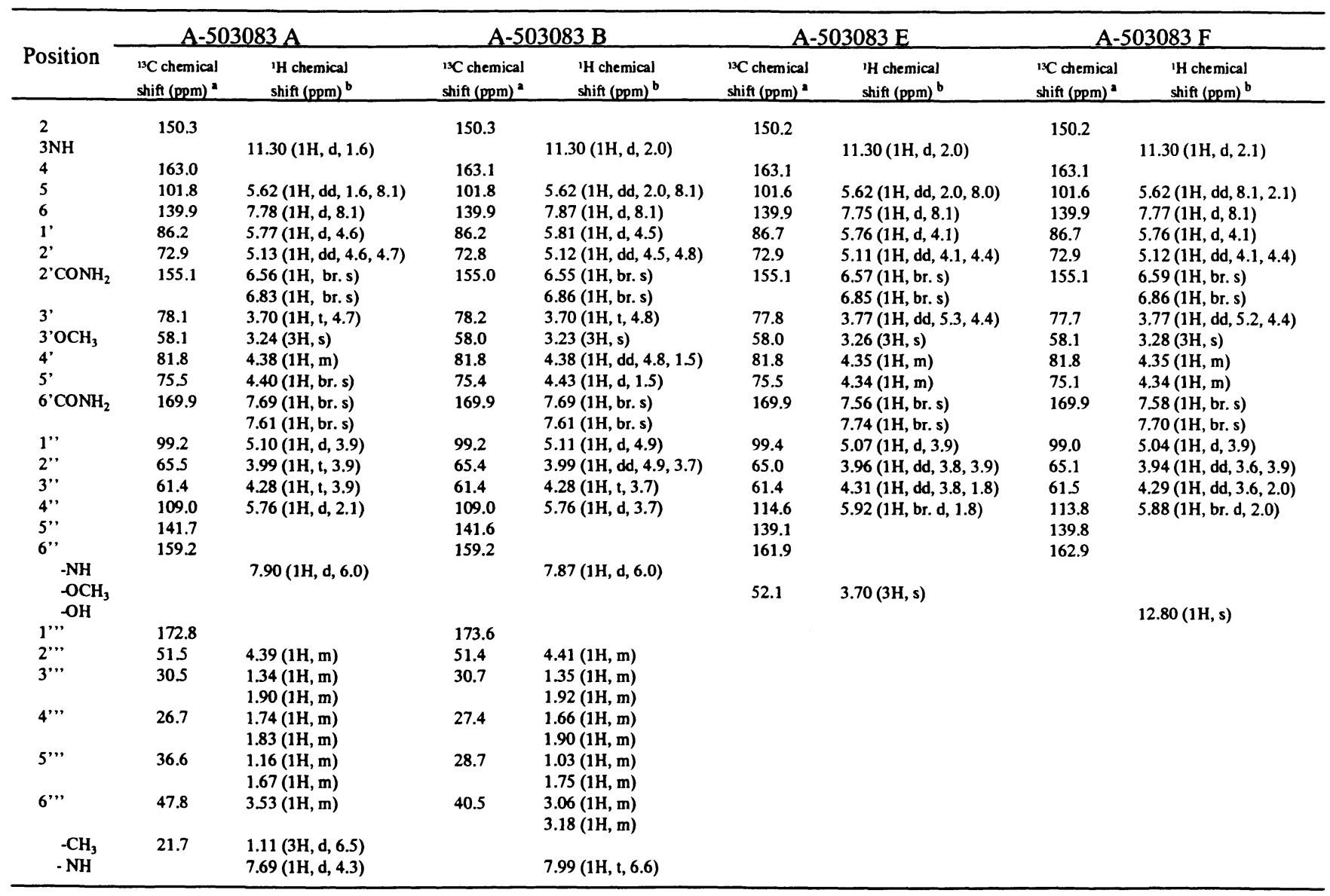

The DMSO- $d_{6}$ signal (39.5 ppm) was used as a reference.

'The DMSO- $d_{6}$ signal (2.05 ppm) was used as a reference.

$6.86 \mathrm{ppm}$ proton signals and the $155.1 \mathrm{ppm}$ carbon signal were assigned to the $2^{\prime}$ - $O$-carbamoyl moiety of A-503083 F (Fig. 4). Observation of a fragment ion at $m / z 458$ assigned as the $\left[\mathrm{M}-\mathrm{CONH}_{2}\right]^{-}$ion of $\mathrm{A}-503083 \mathrm{~F}$ in the ESI LC-MS/MS spectrum supported the conclusion that the structure of A-503083 F was a $2^{\prime}$ - $O$-carbamoyl-derivative of A-500359 F (data not shown).

The structures of A-503083 A, B and E were also elucidated by a comparison study with A-500359 A, B and E, respectively. Since the appearance of ${ }^{13} \mathrm{C}$ and ${ }^{1} \mathrm{H}$ NMR signals derived from the carbamoyl moiety were the same as the characteristic signals of A-503083 A, B and E, their structures were elucidated as 2 '- $O$-carbamoyl derivatives of A-500359 A, B and E, respectively.

Biological Activities of A-503083 A, B, E and F

The translocase I inhibitory activities and antimicrobial
Fig. 4. ${ }^{1} \mathrm{H}-{ }^{13} \mathrm{C}$ HMBC and ${ }^{1} \mathrm{H}-{ }^{15} \mathrm{~N}$ HSQC data of A-503083 F.

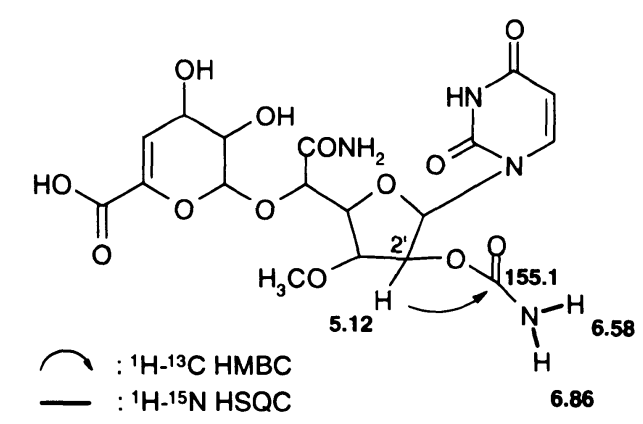

activities of A-503083 A, B, E and F are given in Table 5 and Table 6, respectively. A-503083 A, B, E and F inhibited translocase $\mathrm{I}$ with $\mathrm{IC}_{50}$ values of $0.024,0.038,0.135$ and 
$17.9 \mu \mathrm{M}$, respectively. A-503083 A and B showed antimicrobial activity against Streptococcus pneumoniae, Streptococcus pyogenes, Mycobacterium smegmatis and Mollaxella catarrhalis. A-503083 E had less potent antimicrobial activity than A-503083 A and B. A-503083 F showed no antimicrobial activity so far, in agreement with its relatively weak translocase I inhibitory activity.

\section{Discussion}

In the course of our screening for bacterial translocase I inhibitors, we discovered novel inhibitors, A-503083 A, B, $\mathrm{E}$ and $\mathrm{F}$, and their structures were elucidated as $2^{\prime}-O$ carbamoyl derivatives of A-500359 A, B, E and F, respectively. Although the strain SANK 62799 also produced trace amounts of A-500359 A, B and E (data not shown), the taxonomic studies showed the strain was distinct from Streptomyces griseus SANK 60196, which was previously reported to produce capuramycin and

Table 5. Inhibition of translocase I by A-503083 $\mathrm{A}, \mathrm{B}, \mathrm{E}$ and $\mathrm{F}$.

\begin{tabular}{cc}
\hline $\mathrm{A}-503083$ & $\mathrm{IC}_{50}(\mu \mathrm{M})$ \\
\cline { 2 - 2 } $\mathrm{A}$ & 0.024 \\
$\mathrm{~B}$ & 0.038 \\
$\mathrm{E}$ & 0.135 \\
$\mathrm{~F}$ & 17.9 \\
\hline
\end{tabular}

A-500359s. ${ }^{1,10)}$ It was interesting to note that strain SANK 62799 had a greater tendency to produce $O$-carbamoyl derivatives in addition to A-500359s.

In the previous study A-500359 A, B, E and F were reported to be potent translocase $\mathrm{I}$ inhibitors with $\mathrm{IC}_{50}$ values of $0.017,0.018,0.057$ and $2.4 \mu \mathrm{M}$, respectively. Comparison studies with the $\mathrm{IC}_{50}$ values of A-503083 A, B, $\mathrm{E}$ and $\mathrm{F}$ indicated that the addition of a $2^{\prime}-O$-carbamoyl moiety reduced the inhibitory activity 2- to 8-fold. Consistently, their antimicrobial activities were less potent compared with those of A-500359s. These results indicate that the $2^{\prime}-\mathrm{OH}$ in $\mathrm{A}-500359 \mathrm{~s}$ is important for the inhibitory activity against the translocase $I$. However, this is the first report to show the existence of the $2^{\prime}$ - $O$-carbamoyl derivatives among the series of A-500359s and it is interesting that various strains produce the capuramycin related compounds.

\section{References}

1) Muramatsu, Y.; M. M. Ishil \& M. Inukai: Studies on novel bacterial translocase I inhibitors, A-500359s. II. Biological activities of A-500359 A, C, D and G. J. Antibiotics 56: 253 258, 2003

2) Yamaguchi, H.; S. Sato, S. Yoshida, K. Takada, M. ItOH, H. SETO \& N. Otake: Capuramycin, a new nucleoside antibiotic. Taxonomy, fermentation, isolation and characterization. J. Antibiotics 39: 1047 1053, 1986

3) Seto, H.; N. Otake, S. Sato, H. Yamaguchi, K. Takada, M. ITOH, H. S. M. LU \& J. ClARDY: The structure of a new nucleoside antibiotic, capuramycin. Tetrahedron Lett. 29: 2343 2346, 1988

4) Isono, F.; T. Katayama, M. Inukal \& T. Haneishi:

Table 6. Antimicrobial activity of A-503083 A, B, E and F.

\begin{tabular}{lcrrr}
\hline & \multicolumn{4}{c}{$\mathrm{MIC}(\mu \mathrm{g} / \mathrm{ml})$} \\
\cline { 2 - 5 } \multicolumn{1}{c}{ Microorganism } & A-503083 A & B & E & F \\
\hline \hline Staphylococcus aureus FDA 209P JC-1 & $>100$ & $>100$ & $>100$ & $>100$ \\
Streptococcus pneumoniae SANK 73201 & 25 & 50 & $>100$ & $>100$ \\
Streptococcus pneumoniae SANK 73301 & 100 & 50 & $>100$ & $>100$ \\
Streptococcus pyogenes SANK 73401 & 25 & 50 & 100 & $>100$ \\
Bacillus subtilis ATCC6633 & $>100$ & $>100$ & $>100$ & $>100$ \\
Mycobacterium smegmatis ATCC 607 & 25 & 25 & $>100$ & $>100$ \\
Moraxella catarrhalis SANK 72901 & 6.25 & 6.25 & 25 & $>100$ \\
Escherichia coli NIHJ JC-2 & $>100$ & $>100$ & $>100$ & $>100$ \\
Klebsiella pneumoniae IID865 & $>100$ & $>100$ & $>100$ & $>100$ \\
Enterobacter cloacae IID977 & $>100$ & $>100$ & $>100$ & $>100$ \\
Serratia marcescens IAM 1184 & $>100$ & $>100$ & $>100$ & $>100$ \\
Pseudomonas aeruginosa PAO1 & $>100$ & $>100$ & $>100$ & $>100$ \\
\hline Penillin
\end{tabular}

${ }^{\mathrm{a}}$ Penicillin-sensitive strain.

${ }^{b}$ Penicillin highly resistant strain. 
Mureidomycins $\quad \mathrm{A} \sim \mathrm{D}, \quad$ novel peptidylnucleoside antibiotics with spheroplast forming activity. III. Biological properties. J. Antibiotics 42: 674 679, 1989

5) InUkaI, M.; F. Isono \& A. TAKatsuki: Selective inhibition of the bacterial translocase reaction in peptidoglycan synthesis by mureidomycins. Antimicrob. Agents Chemother. 37: 980 983, 1993

6) Shirling, E. B. \& D. Gottlieb: Methods for characterization of Streptomyces species. Int. J. Syst. Bacteriol. 16: 313 340, 1966

7) Waksman, S. A. (Ed.): Classification, Identification and Description of Genera and Species. The Actinomycetes. Vol. 2, The Williams \& Wilkins, Co., 1961

8) Hasegawa, T.; M. Takizawa \& S. Tanida: A rapid analysis for chemical grouping of aerobic actinomycetes.
J. Gen. Appl. Microbiol. 29: 319 322, 1983

9) Muramatsu, Y.; A. Muramatsu, T. Ohnuki, M. M. Ishil, M. Kizuka, R. Enokita, S. Tsutsumi, M. Arai, Y. Ogawa, T. Suzuki, T. Takatsu \& M. Inukal: Studies on novel bacterial translocase I inhibitors, A-500359s. I. Taxonomy, fermentation, isolation, physico-chemical properties and structure elucidation of A-500359 A, C, D and G. J. Antibiotics 56: 243 252, 2003

10) Muramatsu, Y.; S. Miyakoshi, Y. Ogawa, T. Ohnuki, M. M. Ishil, M. Arai, T. Takatsu \& M. InUkal: Studies on novel bacterial translocase I inhibitors, A-500359s. III. Deaminocaprolactam derivatives of capuramycin: A500359 E, F, H, M-1 and M-2. J. Antibiotics 56: 259 267, 2003 